\title{
A KEY TO NORTH AMERICAN STATIRA (COLEOPTERA: LAGRIIDAE)
}

\author{
By Carl T. Parsons \\ Manchester Depot, Vermont
}

From time to time during the past several years I have studied the Lagriidae with C. W. Leng's excellent collection as a basis. To this collection has been added valuable series especially from the southwest and Mexico generously presented by Dr. Floyd Werner. As indicated in the table of abbreviations below, various public and private collections have been examined. I am deeply indebted to the respective curators and individuals for extending this privilege.*

In the course of this study a few additions to our fauna turned up and a few changes seem advisable. Much more material is needed to clear up still pending problems. An account of Arthromacra will follow.

\section{Key to North American Statira}

I. At least middle and hind tibiae distinctly sulcate along nearly entire outer edge; disc of pronotum scabrous or rugulose .... 2 Tibiae on outer edge rounded or flat (rarely feebly sulcate distally) as in defecta, disc of pronotum variably punctate, intervals between punctures usually alutaceous, rarely smooth

2. Setigerous punctures on first elytral interval not more than 6 , on 3 rd not more than 8 , on 5 th not more than 5 , on 7 th not more than 2, on 9 th not more than 5

Setigerous punctures on first elytral interval not less than IO, on 3 rd not less than 13 , on 5 th not less than 12 , on 7 th not less than IO, on 9th not less than I I

3. Lateral margin of prothorax obliterated anteriorly, becoming distinct posteriorly; pronotum finely scabrous, rich dark

\footnotetext{
* Specimens studied are referred to by abbreviations as follows: (A.M.N.H.), American Museum of Natural History; (A.N.S.P.), Academy of Natural Sciences Philadelphia; (C.A.F.), C. A. Frost collection in M.C.Z.; (C.T.P.), C. T. Parsons collection, Manchester Depot, Vermont; (C.U.), Cornell University; (F.P.B.), Florida Plant Board, Gainesville; (H.C.F.), H. C. Fall collection in M.C.Z.; (H.F.H.), Henry F. Howden collection; (Ill. N. H. S.), Illinois Natural History Survey; (M.C.Z.), Museum of Comparative Zoology; (U.S.N.M.), United States National Museum.

Manuscript received by the editor March 16, 1965.
} 
brown; labrum, base of antennae, and legs paler; subopaque; in both sexes apical antennal segment equal to next $21 / 2$ segments subnitida

Lateral margin of prothorax evanescent anteriorly but just discernible; pronotum densely, minutely, punctulate, rugulose, and opaque; piceous, except prothorax, scutellum, legs, and basal two antennal segments rufo-testaceous; male apical antennal segment equal to next $3 \frac{\mathrm{T}}{2}$ segments colorata

4. Lateral margin of prothorax almost always obliterated anteriorly but starting at the middle becoming distinct posteriorly, rarely the margin continuing obsoletely to the anterior edge; margins of sulcus on fore and middle tibiae similar; pronotum finely rugulose and scabrous, much finer than eye facets; ist elytral interval with II-I 6 setigerous punctures, 3 rd with I 4-2I, 5 th with $12-20$, 7 th with $10-17$ and 9th with $12-20$ setigerous punctures pluripunctata

Lateral margin of prothorax entire and distinct; either anterior or posterior margin of sulcus on fore and mid tibiae raised to form a blackish carina; pronotum moderately coarsely scabrous, about as course as eye facets; Ist elytral interval with $20-28$, 3rd with $2 \mathrm{I}-26$, 5th with $22-26$, 7 th with $22-28$, and 9th with 22-35 setigerous punctures

hirsuta

5. Elytra testaceous to rufous with brown to black markings; no setigerous punctures on 5 th elytral interval (except rarely I at apex)

Elytra unicolorous, usually dark (testaceous in teneral examples); several setigerous punctures on 5 th elytral interval ............ 7

6. Male apical antennal segment equal to next 5 segments, in female equal to next $3 \frac{1}{2-4}$ segments; testaceous to rufous, elytra slightly paler, with large scutellar spot and transverse fascia, slightly behind middle and wider at sides than at middle, brown or black; O-I setigerous puncture at base of Ist elytral interval, 3rd elytral interval with $4-6$ from base to apex, 7 th with 2 at base, 9th with 4 along apical fourth ....... pulchella

Male apical antennal segment equal to next 4-4 I/5 segments, in female equal to next 3 segments; rufo-testaceous, median black spot on each elytron not reaching the suture; 3rd elytral interval with 5-9 setigerous punctures, 7th with 2 at base, 9th with 3-4 along apical fourth .................. nigromaculata

7. Setigerous punctures on Ist elytral interval i $9-26$, on 3 rd interval I8-33, on 5 th interval $17-23$, on 7 th interval $8-13$, on 9 th interval 8-24 
Setigerous punctures on Ist elytral interval $2-5$, on 3 rd interval 4 - I 5 , on 5 th interval 4 -II, on 7 th interval $2-8$, on 9 th interval 4 -I I

8. Setigerous punctures on ist elytral interval about 25 , on 3 rd interval 26-33, on 5th interval $\mathrm{I} 7-23$, on 7 th interval 8-I3, on 9th interval 8-I7; setigerous punctures about as large as strial punctures, pronotum opaque, male apical antennal segment equal to next $4 \frac{1}{4}$ segments, in female equal to next 3-3/4; length 9-I I mm. opacicollis

Setigerous punctures on first elytral interval i9-25, on 3 rd interval $18-2 \mathrm{I}$, on 5 th interval about 18 , on 7 th interval about 8 , on 9 th interval about 24 ; setigerous punctures at least twice as large as strial punctures; pronotum sub-opaque; male apical antennal segment equal to next $33 / 4-4$, in female equal to next 3 ; length $\mathrm{I} 2.5-\mathrm{I} 4 \mathrm{~mm}$. huachucae

9. Fore and middle tibiae rounded on outer edge; male apical antennal segment equal to next $33 / 4-7$ segments, in female equal to next $2 \mathrm{~T} / 2-4$ segments

Fore and middle tibiae flat on outer edge (rarely feebly sulcate distally); male apical antennal segment equal to next $2 \mathrm{r} / 2-23 / 4$ segments, in female equal to next $2-2 \mathrm{~T} / 4$ segments; disc of pronotum very densely and finely punctate, the punctures less than their diameters apart, the surface finely alutaceous; setigerous punctures on Ist elytral interval $4-5$, on 3 rd interval $3-6$, on 5 th interval $3-5$, on 7 th interval $1-3$, on 9 th interval $5-6$ defecta

IO. Disc of pronotum with punctures on the average at least 3 times their diameter apart; elytra brown to black (except bluish in croceicollis

Disc of pronotum with punctures separated by about their diameter; rufous, legs testaceous, abdomen piceous, elytra black with metallic bluish-green lustre; setigerous punctures on $3 \mathrm{rd}$ elytral interval 5-7, on 5th interval $4-5$, on 7 th interval 2 at base, on 9th interval about 6; male apical antennal segment

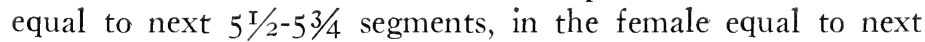
$3 \frac{\mathrm{T} / 4}{4}$ segments; length 9 -IO $\mathrm{mm}$.

liebecki

II. Setigerous punctures on 3rd elytral interval 7 -I $5 \ldots \ldots \ldots \ldots \ldots$ I2

Setigerous punctures on 3 rd elytral interval $3-5 \ldots \ldots \ldots \ldots \ldots \ldots$ I 3

I2. Length I0.5-I $2.5 \mathrm{~mm}$; male apical antennal segment equal to next $33 / 4-4 \mathrm{I} / 3$ segments, in female equal to next $2 \mathrm{r} / 2-3$ segments; brown to piceous black, head darker; setigerous punctures on 3 rd elytral interval IO-I5, on 5 th interval about II, 
on 7 th interval 5 on basal three-fifths, on 9th interval 8-I I robusta

Length 7-9.5 mm.; male apical antennal segment equal to next 43/4-5 segments, in female equal to next 3-3/2 segments; prothorax and legs testaceous or rufous, head piceous, elytra piceous or black, the elytra with a distinct bluish lustre; setigerous punctures on 3 rd elytral interval 7-I4, on 5th interval 7-I2, on 7 th interval either 2 at base or 6-8 all along, on 9 th interval 5 -I 3 croceicollis

13. Setigerous punctures of elytra about the same size as the strial punctures; larger, 8-I I.5 mm.

I 4

Setigerous punctures of elytra about twice as large as the strial punctures; smaller, $6.5-8.8 \mathrm{~mm}$.

I4. Posterior margin of fifth ventral segment produced around a distinct fovea; male apical antennal segment equal to next $+2 / 3-5$ segments, in the female equal to next $32 / 3-33 / 4$ segments; color paler, tending to brown rather than piceous, elytra tending to brown especially along sutural margins

dolera n. sp.

Posterior margin of fifth ventral segment simple, without fovea; male apical antennal segment equal to next $6 \mathrm{~T} / 2-7$ segments, in the female equal to the next 4 segments or slightly less; color darker, tending to piceous black, elytra sometimes slightly more pale and with very narrow brown sutural margins

basalis

I5. Pronotum brownish piceous to piceous black usually concolorous with elytra; male apical antennal segment equal to next $5 \frac{\mathrm{T}}{2}$ segments, in the female equal to next $3 \mathrm{I} / 3$ segments, range Vermont to $W$ isconsin south to North Carolina and Tennessee gagatina gagatina

Pronotum testaceous to brownish rufous, head and elytra brownish piceous to piceous black; male apical antennal segment equal to next $5 \frac{1}{2}-61 / 2$ segments, in the female equal to next $3 \mathrm{I} / 3$ segments; range more southern, New York City to Alabama, also Michigan gagatina resplendens

\section{Statira subnitida Leconte}

Statira subnitida Lec., 1866, Smithsonian Misc. Coll., Wash., 167: 141-142. Types: lectotype $\sigma^{\top}$ (not 9 as Horn stated) no. 4749 and I 9 cotype collected by John Xantus at Cape San Lucas, Baja California, in M.C.Z.

Range: Known only from Baja Califronia, Mexico, from the two 
types and female from Santa Rosa (H.C.F. in M.C.Z.). In the Horn collection (A.N.S.P.) are three specimens identified as subnitida in Horn's handwriting. The first from San Jose del Cabo is colorata and the other two are defecta from "Ariz".

\section{Statira colorata Fall}

Statira colorata Fall, 1909, Canadian Entomologist, 41: 165-166.

Types: holotype $\sigma^{7}$ no. 246r3 collected by Charles Fuchs at San José del Cabo, Baja California, Mexico (H.C.F.) With identical data are two males in the Casey collection (U.S.N.M.) and one male in the Horn collection (A.N.S.P.)

\section{Statira pluripunctata Horn}

Statira pluripunctata Horn, 1888, Trans. Amer. Ent. Soc. 15: 29.

Statira sulcicrus Champion, 1889, Biol. Centr.-Amer. Coleop. 4(2): 51-52. NEW SYNONYMY.

Types: of pluripunctata lectotype $q$ no. 8018 from Arizona (A.N.S.P.) and i o evidently a cotype in the Leconte coll. (M.C.Z.) Of sulcicrus $2 \sigma^{\pi} \sigma^{\pi}$ and 2 우 cotypes collected by Hoge at Chilpancingo, Guerro, Mexico in the British Museum.

In the United States this common species is most nearly allied to hirsuta. But in must be nearer pueblensis Champion (not seen), which is said to be more stout, antennae less slender, hairs on femora longer, and pronotum densely, finely, and irregularly punctate and wrinkled, with prothorax more distinctly margined. Champion's sulcicrus is made a synonym from description only.

G. H. Nelson has collected in Arizona two examples which do not key out. A male taken on Ephedra trifurca, Aug. 28, I954, at Portal has setigenous punctures on base only of first elytral interval and half the normal number of punctures on the other intervals. The other specimen, collected at light in Sabino Canyon, Santa Catalin Mts. Aug. 25, I959, has typical male terminalia but only 4 setigerous punctures on first, IO punctures on third, and 7 punctures on fifth elytral interval.

Range: This species occurs from June 20 to Sept. 20 , chiefly late July to early August in southern Utah: state label (C.T.P.), St. George (C.U., A.M.N.H.), South Creek, Beaver Co. (C.U.) Texas: Alpine (C.U., H.C.F.), 2 and 15 miles west of Fort Davis (H.F.H.) New Mexico: La Cueva, Organ Mts. (H.C.F.); Arizona: Cochise Co., Santa Cruz Co., Pima Co., Pinal Co., Gila Co., Maricopa Co., Yavapai Co.; Mexico: Sonora (A.M.N.H.), Chihuahua (A.M.N.H., C.T.P.) Durango (A.M.N.H., C.T.P.), Guerrero (B.M.) 
Habitat: It has been collected on cotton, Datura meteloides, and from leaf axils of Yucca with dead flowers in them. Werner and Nutting have taken it at light in the following plant associations in Arizona (C.T.P.): Larrea, mesquite-cholla, chaparral, sycamoreoak-ash, and mesquite-desert grassland.

\section{Statira hirsuta Champion}

Statira hirsuta Champion, 1889, Biol. Centr.-Amer. Coleop. 4(2): 50-51.

Statira simulans Schaeffer, 1905, Journ. New York Ent. Soc. 13: 180. NEW SYNONYMY.

Types: of hirsuta cotypes from "Mexico (coll. F. Bates), Jalapa, Iguala in Guerrero, Tapachula in Chiapas (Hoge); Nicaragua, Chontales (Belt) all in the British Museum. Jalapa is here designated the type locality since a series, of which two are in the A.M.N.H., was collected there. Of simulans from Brownsville, Texas (U.S.N.M.).

Range: In the United States hirsuta occurs from June 7 to August 8 in southeastern Texas at Brownsville, usually at the Esperanza Ranch. Also in the authors's collection is a specimen taken by Henry Wenzel in Dimmit Co., 250 miles northwest of Brownsville. The species extends through Mexico: (May 24 to August 22) Nuevo Leon, Tamaulipas, Vera Cruz, Mexico City, Guerrero, Chiapas to Nicaragua.

Habitat: F. Werner and W. Nutting collected hirsuta at light in desert shrub in Nuevo Leon and at light in mesophytic forest in Tamaulipas.

\section{Statira pulchella Mäklin}

Statira pulchella Mäklin, 1863, Act. Soc. Sci. Fenn. 7: 589. Reprinted April 13, 1863, pp. 101-2. Figured by Champion, 1889, Biol. Centr.-Amer. pl. 2 , fig. 8 .

Type: from Mexico presumably in the Zool. Mus. in Helsinki.

Range: This species occurs in the United States in extreme southeastern Texas at Brownsville where J. N. Knull collected a series on June I-8, I934 (H.C.F.) In Mexico it has been taken on the Atlantic slope in Vera Cruz: Jalapa (B.M., A.M.N.H.), Cordova (B.M.), Atoyac (B.M.) and in eastern San Luis Potosi: Tamasunchale (C.T.P.)

Habitat: F. Werner and W. Nutting took the Tamasunchale specimen at light in open river bottom on May 30.

\section{Statira nigromaculata Champion}

Statira nigromaculata Champion, 1889, Biol. Centr.-Amer. Coleop. 4(2): 33-34, pl. 2, fig. 9. 
Types: from Mexico: Jalapa in Vera Cruz and Yolos in Oxaca; Guatemala: San Geronimo in the British Museum.

Range: This rare species occurs in southeastern Arizona: Aug. 6, I948, Geronimo, Graham Co. (C.T.P.) ; July I-I 5, I923, Baboquivari Mts. (H.C.F.) ; July 18, I948, Sonoita River, Patagonia, Santa Cruz Co. (A.M.N.H.); at light July 7, 1957 and at light July 26, 1948, Sabino Canyon, Santa Catalina Mts. (C.T.P., C.A.F.) ; Texas: July 20, 1956, 2 miles west of Ft. Davis (H.F.H., G.N., C.T.P.) ; July 26, 1956, Limpia Canyon near Ft. Davis (C.U.) ; Mexico: July I 4 and I 5, I947, Camargo and I 5 miles east of Parrah in Chihuahua (A.M.N.H.) ; also the above type localities. Habitat: H. \& A. Howden took a series at Ft. Davis on willow. Werner and Nutting took a series at light in the sycamore-oakmesquite association in Sabino Canyon and the Geronaimo, Arizona specimen in willow-mesquite-cottonwood association.

\section{Statira opacicollis Horn}

Statira opacicollis Horn, 1888, Trans. Amer. Ent. Soc. 15: 30.

Types: lectotype $\sigma^{\top}$ no. 8017 collected by Morrison in Arizona (A.N.S.P.). Two evident cotypes are in the Leconte coll. (M.C.Z.) Range: This rare species is known definitely from southeastern Arizona in Gila Co.: Sierra Ancha Mts. (C.U.) and Cochise Co.: Chiricahua Mts. A series of 67 specimens were taken by M. Statham May 3-19, 1956 at $5400 \mathrm{ft}$. five miles west of Portal, Cochise Co., Arizona (A.M.N.H., C.T.P., C.A.F.)

\section{Statira huachucae Schaeffer}

Statira huachucae Schaeffer, 1905, Science Bull. of the Museum of the Brooklyn Inst. of Arts and Sciences 1(7): 176.

Types: cotype $\sigma^{\pi}$ and cotype $O$ both no. 42558 (U.S.N.M.), both labelled "type" in Schaeffer's writing. They were collected by Charles Schaeffer June I3, I4 in the Huachuca Mts. Arizona. Range: This rare species is known from southeastern Arizona: July I4, I952, Madera Canyon, Santa Rita Mts. in Pima Co., George Bradt (A.M.N.H.) ; July, Palmerlee, Cochise Co. (C.T.P.) ; and the following records from the Huachuca Mts.: July 1905 (C.T.P.); July I 4, I928, 6000 ft., A. A. Nichol (C.U.) ; July I 4, I928, 6000 ft., A. A. Nichol (C.U.); June 24 and July I3 (C.U.).

Champion (r889, p. 30) described Statira alternans based on a unique male from Tepansacualco, Mexico. It is possible that huachucae and alternans are identical. A specimen that is questionably alternans was taken June 4, 1948 at $8000 \mathrm{ft}$. at Gaborachic, Chihuahua, Mexico by George Bradt (A.M.N.H.). 


\section{Statira defecta Schaeffer}

Statira defecta Schaeffer, 1905, Science Bull., Mus. Brooklyn Inst. of Arts and Sciences. $1(7): 175$.

Type: Holotype no. 42557 Palmerlee, Cochise Co., Arizona (U.S.N.M.)

Range: This common species occurs in southeastern Arizona and adjoining New Mexico from July 5 to September 3, preponderantly during the latter half of July. In Arizona it extends from extreme southern Navajo Co., Gila Co., Pima Co., Santa Cruz Co., to Cochise Co., and across into Hidalgo Co., New Mexico.

Habitat: Werner and Nutting have taken it at light in the following plant associations in Arizona (C.T.P.) : cholla-mesquite, chaparrel, oak-hackberry, sycamore-oak-mesquite, and rich mesophytic valley in pine zone.

\section{Statira liebecki Leng}

Statira licbecki Leng, 1923, Journ. New York Ent. Soc. 31: 185-187.

Types: holotype $\sigma^{x}$ from Enterprise, Florida and allotype $q$ collected by H. P. Loding May I5, I9r9 at Spring Hill, Alabama, both in author's collection (ex coll. C. W. Leng).

Range: This very rare spring species is known from the following records in addition to the above mentioned types: two male paratypes no. 26543 from Enterprise, Florida (H.C.F. ex Liebeck coll.); one male collected by H. P. Loding at Orchard, Alabama (H.C.F.) ; one female paratype, April 24, Crescent City, Florida (A.M.N.H.) and one paratype collected by W. T. Davis, April 29 at South Bay, Lake Okeechobee, Florida in Staten Island Inst. of Arts and Sci.; one male collected and presented by H. V. Weems, Jr. at Highland Hammock State Park, Florida on March 2O. (C.T.P.)

This species appears to be closely related to or possibly identical with var. a of Statira mexicana Champion which occurs on the eastern slope of Mexico.

\section{Statira robusta Schaeffer}

Statira robusta Schaeffer, 1905, Journ. New York Ent. Soc. 13: 180.

Type: holotype $q$ no. 42556 collected by Charles Palm at Globe, Arizona (U.S.N.M.)

Range: This species occurs May to August in Colorado: Colorado Springs (Ill. N. H. S.) ; Arizona: Yavapai Co.; Maricopa Co., Gila Co., Cochise Co.; New Mexico: San Miguel Co., Otero Co.; Texas: Brewster Co.

Habitat: Werner and Nutting collected robusta on July 9 at light 
in the pinon-juniper-oak association in the Chisos Mts. of Texas (C.T.P.).

Evidently robusta is closely related to or possibly identical with tuberosa which Champion described, p. 3I, from one female from Jalapa, Mexico. So far no Mexican examples have been seen.

\section{Statira croceicollis Mäklin}

Statira croceicollis Mäklin, 1863, Act. Soc. Sci. Fenn. 7: 594. ReprintedApril 13, 1863, p. 106.

Type: collected by Motschulsky at Mobile, Alabama; presumably in the Zool. Mus. in Helsinki.

Range: This early spring species has been collected during March 9 to April 24 most often in peninsular Florida: Dunedin (H.C.F., C.U.), Enterprise (C.T.P., H.C.F.), Jupiter (M.C.Z., Ill. N.H.S.), Kissimmee (A.M.N.H.), Lake Worth (C.U.), Biscayne (A.N.S.P.), Miami (CT.P.), Paradise Key (H.C.F., C.A.F.), Key Largo (A.M.N.H.) There are two specimens from Georgia: St. Simons Island (C.T.P.), "Geo." (H.C.F.) ; two specimens from Mississippi: Ocean Springs (C.U.), Lucedale (C.U.); and a female collected by A. Nicolay on June 23, I933 at Chesapeake Beach, Maryland (H.C.F.)

\section{Statira dolera new species}

fig. I.

Having the appearance of a teneral basalis but a little larger and distinctly larger than gagatina. The color tends to be more pale than basalis with the sutural margins of the elytra more pale than the rest of the elytra; shining, piceous, with the head darker and the elytra usually more pale, legs testaceous to brown with a tendency for the apices of the femora to be darker. Antennae and anterior part of head rufous. Vertex narrower than in gagatina, densely rather coarsely punctate, much more coarsely punctate than pronotum but a little more finely punctate than elytral striae. Eleventh antennal segment as long as Ioth, 9th, 8th, 7 th, and $3 / 4$ of 6 th to all of 6th segments combined in the male and as long as the roth, 9 th, 8th, and $2 / 3-3 / 4$ of 7 th segments combined in the female. Prothorax of holotype with width/length as $1 / .90$, in the allotype as I/.93; anterior margin truncate or very feebly emarginate, sides more rounded than in gagatina or basalis, posterior margin truncate, lateral line distinct and entire, disc very finely and sparsely punctate, the punctures about $6 \times$ their diameters apart, the intervals very finely granular. In the allotype and some paratypes the punctures 

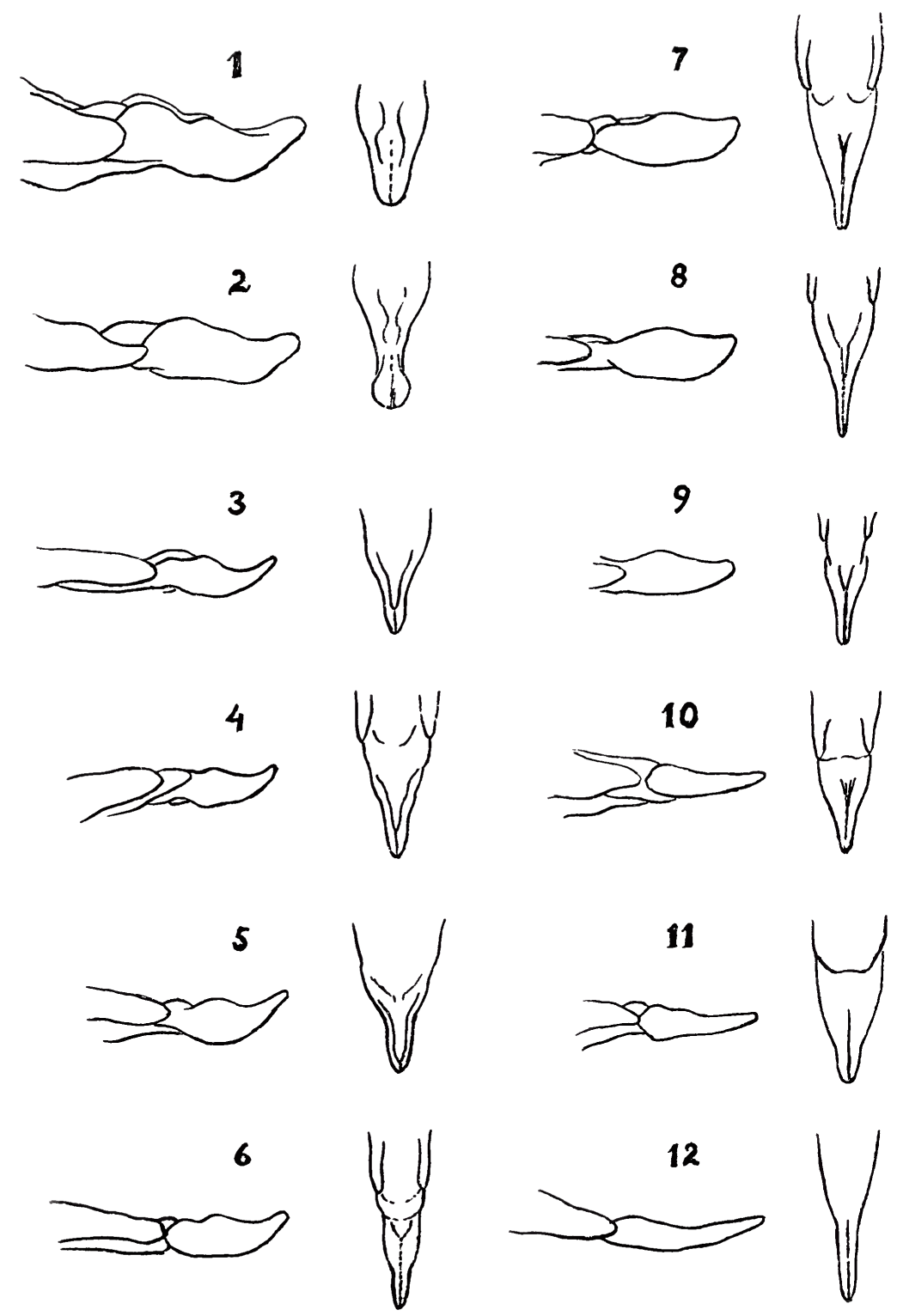

Parsons - Statira 
may be variably obsolete and the intervals almost smooth. Scutellum distinctly or obsoletely granular and distinctly or obsoletely very finely punctate.

Elytra striate with closely placed punctures along the striae, the intervals moderately convex and with the setigerous punctures the same size as the strial punctures. In presenting the numbers of setigerous punctures along the elytral intervals the first figure is of the holotype, the second where present of the allotype, and figures in parentheses represent variations in the paratypes. First elytral interval with I setigerous puncture at base and 2 (3) at apex, 3rd interval with $6,5(5-8)$ setigerous punctures placed all along, the 5 th interval with $6,4(4-6), 7$ th interval with 2,2 at base (there may also be I at apex), 9th interval with 6, 7 (5-II) along apical half. Femora glabrous, tibiae rounded on outer edge. In both sexes the posterior margin of the fifth ventral segment is produced around a distinct fovea, a character lacking in our other species. Male terminalia as figured. Holotype: length $10.7 \mathrm{~mm}$., width of prothorax $1.95 \mathrm{~mm}$., width of elytra at humeri $2.9 \mathrm{~mm}$.; allotype: length $9.3 \mathrm{~mm}$., width of prothorax I. $6 \mathrm{~mm}$., width of elytra at humeri $2.5 \mathrm{~mm}$. For this species the dimensions of the holotype are typical whereas dimensions of the allotype are minimum.

Range: All the specimens were taken from February I9 to May I-I 2 in Florida as follows. Holotype $\sigma^{\star}$ Gainsville, H. L. Dozier (C.T.P. ex C. W. Leng); allotype + April I, I947, Lake Placid, J. W. Green (C.T.P.). The following are designated paratypes. Io April, Enterprise (C.T.P.) ; Iㅇ Key West (C.T.P.) ; 2 우우, I $0^{x}$ Florida (C.T.P., H.C.F.) ; I $0^{\top}$ March 5, i939, Edgewater, C. A. Frost (C.A.F.) ; $20^{\top} \sigma^{\top}$ April 6, I929 Dunedin, W. S. Blatchley (C.U., C.A.F.), ㅇ washup Feb. 26, I939 Coronado Beach, C. A. Frost (C.A.F.); I $0^{\star}$ Feb. I9, Crescent City, Hubbard \& Schwarz (U.S.N.M.) ; I $0^{\top}$ Florida, Hubbard \& Schwarz (U.S.N.M.) ; I $0^{\star}$ March I, Haulover, Hubbard \& Schwarz (U.S.N.M.) ; iq March 5, 1948, Gainsville, L. A. Hetrick (Florida Plant Board) ; Florida, A. T. Slosson-(A.M.N.H.) ; I ơ Lake Worth, A. T. Slosson (A.M.N.H.) ; 2 Ormond, A. T. Slosson (A.M.N.H.) (M.C.Z.) ; I $\sigma^{\pi}$ Orange Grove, O. Seifert (C.T.P.) ; iq March 2O, I955 and $3 \sigma^{\pi} \sigma^{\top}, 48$ of March 23-30, I954, Oneco, Manatee Co. (C.U.,

\section{Explanation of Plate 18}

Figs. 1-12. Lateral and dorsal views of the terminalia of Statira. 1. dolera n. sp. 2. basalis. 3. gagatina. 4.gagatina resplendens. 5. species "S. Cal." 6. liebecki. 7. huachucae. 8. robusta. 9. opacicollis. 10. pluripunctata. 11. colorata. 12. simulans. 
C.T.P.); I May I-I2, I955, Welaka (C.U.); 2 Florida (Ill. N.H.S.) ; March 6, I927, Micanopy (C.U.) ; March 6, I945, Lake Placid (C.U.) ; 4 at light March II, I956, Titusville (H.F.H.); I3 Georgetown, March, April (M.C.Z.); iq Sebastian (M.C.Z.); I $0^{\star}$ I우 Waccassa River, Gulf Hammock, Levy Co. March 20, I95+ (C.U.)

Relationships: This species is most nearly related to basalis (Fig. 2), but averages larger, paler, and has shorter apical antennal segments, and distinctive hypopygidium and male terminalia (Fig. I). Also the pronotum is usually more finely and sparsely punctate and the elytral intervals usually more convex.

\section{Statira basalis Horn}

Statira basalis Horn, 1888, Trans. Amer. Ent. Soc. 15: 31-32.

Type: lectotype no. 8016 from Florida in Acad. Nat. Sci. Philadelphia.

Range: This species occurs from February i 5 to June, chiefly during April from North Carolina: Lake Mattamuskeet, Wilmington; South Carolina: Camden, Sampit; Geongia: Atlanta, Clarke Co.; to northern Florida: St. Johns Co., Rock Bluff, Osceola Nat. Forest; west through Alabama: Washington Co., Hazen, Florala, Mobile; Mississippi: Lafayette Co., Oxford, Richton, Lucedale; Louisiana: Vowell's Mill; Missouri: Poplar Bluff; Arkansas: South West, Cove Lake near Paris, Mt. Magazine; to Texas: Dallas.

Habitat: At Hazen, Alabama L. B. Woodruff beat basalis from oak and Crataegus blossoms in April.

\section{Statira gagatina gagatina Melsheimer}

Fig. 3

Statyra gagatina Melsh., 1846, Proc. Acad. Nat. Sci. Philadelphia 2: 311. Statyra resplendens var. fusca Melsh. ibid. New synonymy.

Types: of gagatina lectotype from Pennsylvania in Melsheimer collection (M.C.Z.) The lower of two specimens on one pin is designated the lectotype. What Leconte chose as type and labelled " $S$. gagatina ! Mels." is basalis Horn. Of var. fusca holotype labelled "var. fusca Melsh." in Melsheimer's handwriting in the Melsheimer collection (M.C.Z.)

The variability of gagatina has led to confusion which cannot yet be cleared up. The color varies from pale brown to black, the paler specimens being teneral. As Leng points out (Journ. N.Y. Ent. Soc. 3I: I86-7) gagatina means "like asphalt or jet". Melsheimer described gagatina as "black, tinged with bluish, glossy". But specimens in his collection are brown to piceous. My notes on the 
lectotype read "dark brown". Melsheimer described fusca as "uniformly yellowish-brown". It is just like teneral northern examples of gagatina. There is an occasional tendency for the pronotum to be paler than the head and elytra as in resplendens. The more extreme variations are discussed under resplendens and "sp. near gagatina". Range: This species occurs, March 29 to July 25 chiefly in May, from southern Vermont: Bennington Co.; Massachusetts: Woods Hole, Marion; to North Carolina: Bell Island; Tennessee: Bristol, Knoxville; Arkansas: "Ark." (IIl. N. H. S.) a doubtful dealer's label; Iowa and Wisconsin.

Habitat: Melsheimer collected gagatina in June on leaves of black oak and service berry. It has also been taken by beating apple, hickory, sweet gum, wild cherry, and Pinus virginiana.

\section{Statira gagatina resplendens Melsheimer}

\section{Fig. 4}

Statyra resplendens Melsh., 1846, Proc. Acad. Nat. Sci. Philadephia 2: 311. Type: described from Pennsylvania. Leconte has stated that the unique types of Melsheimer are in his collection. Some of these were subsequently returned to the Melsheimer collection. In the Leconte coll. (M.C.Z.) is a specimen labelled "S. resplendens! Mels." which means Leconte considered it the type. Unfortunately the locality label is an orange disc which indicates "southern states".

This name is questionable. It stands for gagatina in the more southern part of its range with a more or less rufous pronotum and last antennal segment a little longer. The most distinctive specimen seen is a male, July 4, I925, Oakland Co., Michigan in the G. H. Nelson collection. This specimen has the last antennal segment equal to the next $61 / 2$ segments. Its slightly different terminalia is figured. Only very few specimens, ranging from New York City to Alabama, have been seen.

\section{Statira sp. near gagatina}

\section{Fig. 5}

In the collection of the Illinois Natural History Survey (Andreas Bolter coll.) is a male labelled "S. Cal." It is evidently closely related to gagatina but has a shorter last antennal segment, fewer setigerous punctures, and slightly deeper terminalia. Also the pronotum is more sparsely and finely punctate than in gagatina. The locality label is suspiciously like that of an unreliable dealer's.

The color, probably teneral, is testaceous with head brown between the eyes. Last antennal segment as long as next $4^{1 / 2}$ segments. All tibiae rounded on outer edge; all femora glabrous. Pronotal mangins 
distinct and entire. Last ventral segment simple. Disc of pronotum with five punctures averaging about $4 \times$ their diameters apart, surface finely granular. Setigerous elytral punctures about twice as large as strial punctures. Setigerous punctures as follows. Left elytron: Ist interval $I$ at apex, 3rd interval 2 at apical fourth; 5th interval with $I$ at base and $I$ at apical fifth; 7 th interval 2 at base; 9th interval 5 along apical fourth. Right elytron: Ist interval I at base, 3rd interval 1 at apical fifth, 5th interval $I$ at basal fourth and I at apical fifth; 7 th interval 2 at base, 9th interval 5 along apical fifth. Elytral punctures, striae, and convexity of intervals as in gagatina. Length $7.5 \mathrm{~mm}$. 


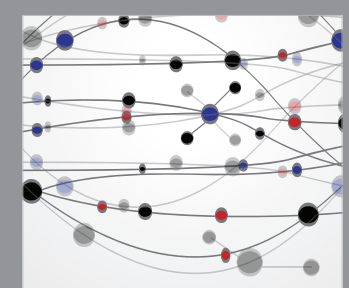

The Scientific World Journal
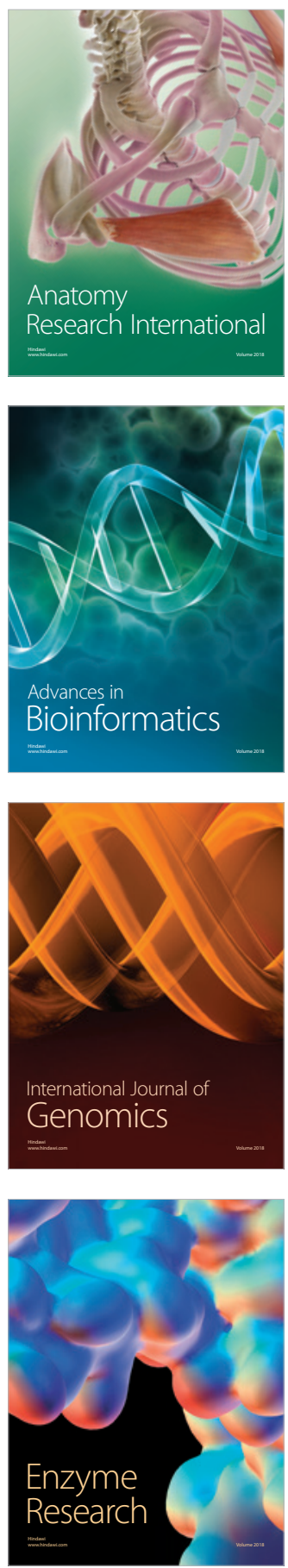
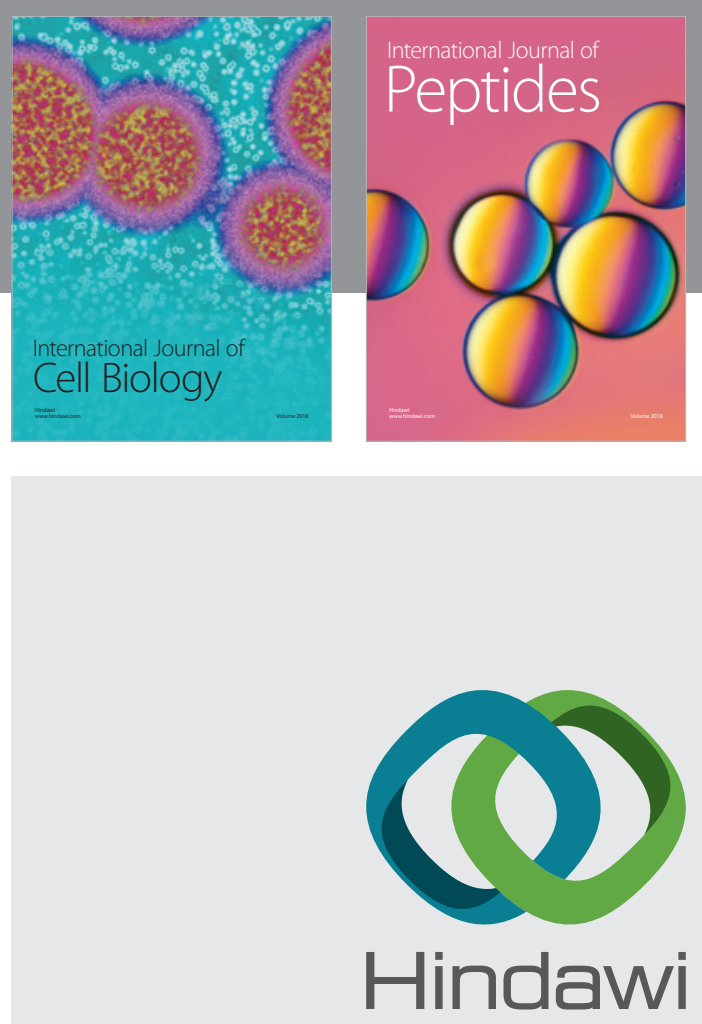

Submit your manuscripts at

www.hindawi.com
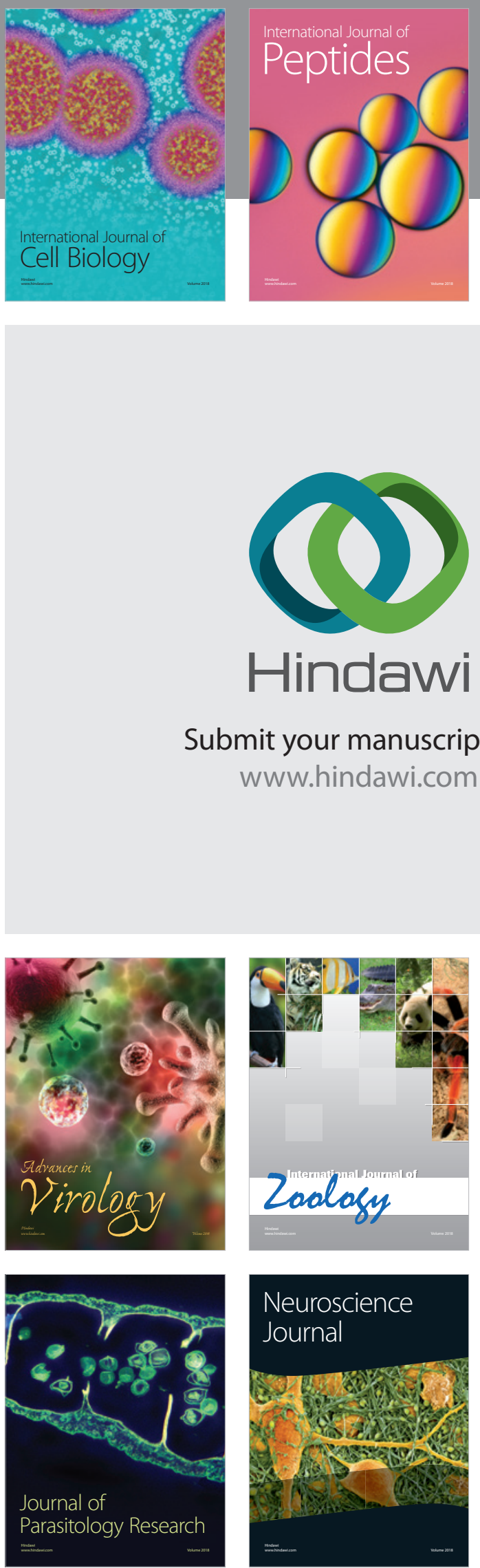
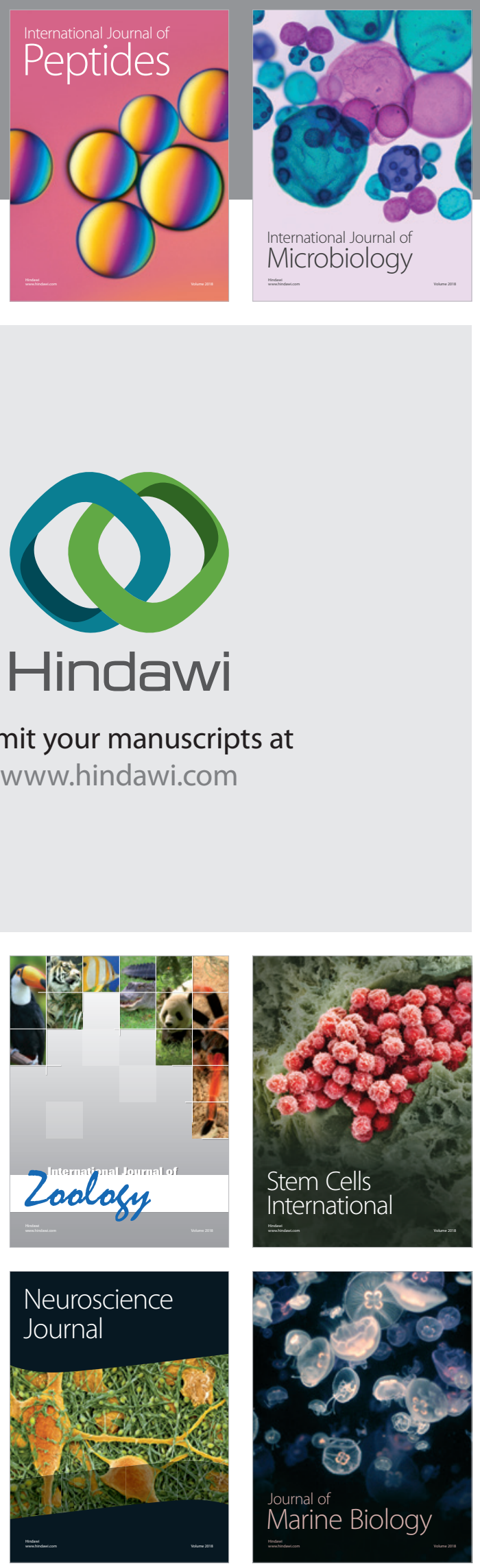
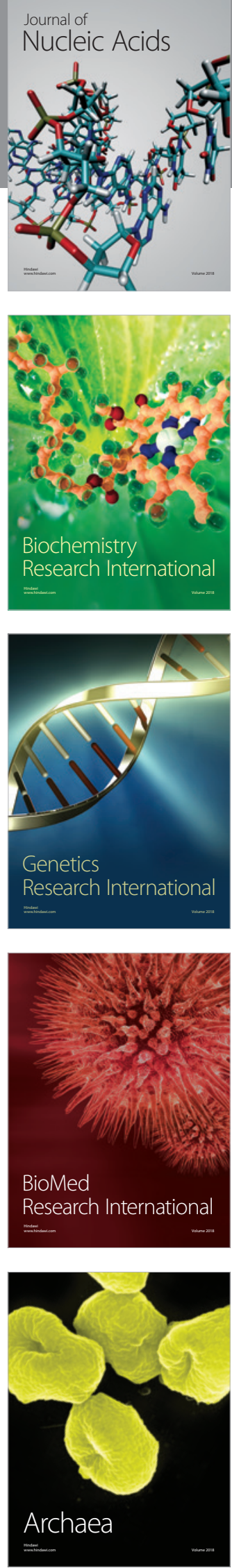